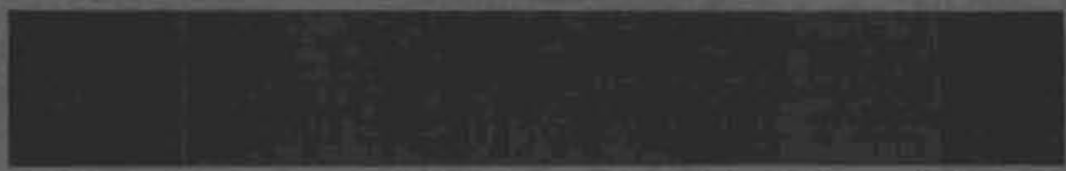

NUCLEAR REACTOR SYSTEM

NOISE ANALYSIS,

DRESDEN I REACTOR,

COMMONWEALTH EDISON COMPANY

OCTOBER 1968

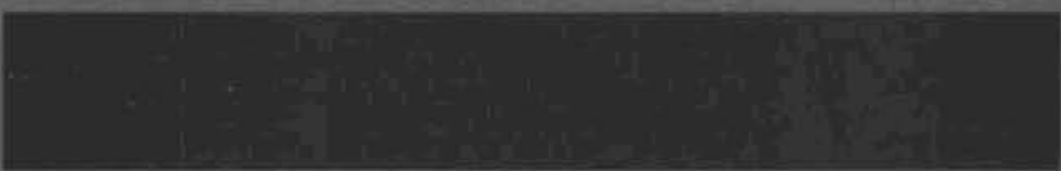

AEC RESEARCH \& DEVELOPMENT REPORT

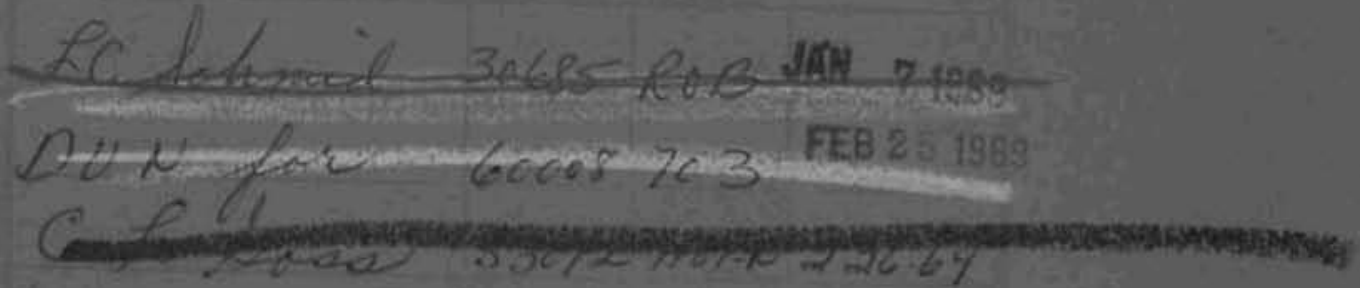

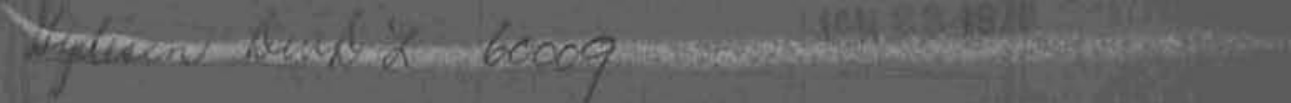

BATTELLE B NORTHWEST

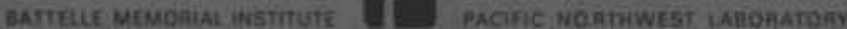

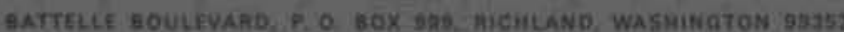




\section{LEGAL NOTICE}

This report was prepared as an account of Government sponsored work. Neither the United States, nor the Commission, nor any person acting on behalf of the Commission:

A. Makes any warranty or representation, expressed or implied, with respect to the accuracy, completeness, or usefulness of the information contained in this report, or that the use of any information, apparatus, method, or process disclosed in this report may not infringe privately owned rights; or

B. Assumes any liabilities with respect to the use of, or for damages resulting from the use of any information, apparatus, method, or process disclosed in this report.

As used in the above, "person acting on behalf of the Commission" includes any employee or contractor of the Commission, or employee of such contractor, to the extent that such employee or contractor of the Commission, or employee of such contractor prepares, disseminates, or provides access to, any information pursuant to his employment or contract with the Commission, or his employment with such contractor.

\section{PACIFIC NORTHWEST LABORATORY \\ RICHLAND, WASHINGTON \\ operated by \\ BATTELLE MEMORIAL INSTITUTE}

for the

UNITED STATES ATOMIC ENERGY COMMISSION UNDER CONTRACT AT(45-1)-1830 


\title{
NUCLEAR REACTOR SYSTEM \\ NOISE ANALYSIS, DRESDEN I REACTOR, COMMONWEALTH EDISON COMPANY
}

\author{
P.H. Hutton \\ Nondestructive Testing Department \\ Systems and Electronics Division
}

October 1968

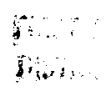

BATTELLE MEMORIAL INSTITUTE

PACIFIC NORTHWEST LABORATORY RI CHLAND, WASHINGTON 
Printed in the United States of America Available from

Clearinghouse of Federal Scientific and Technical Information

National Bureau of Standards, U.S. Department of Commerce Springfield, Virginia 22151

Price: Printed Copy $\$ 3.00$; Microfiche $\$ 0.65$ 
TABLE OF CONTENTS

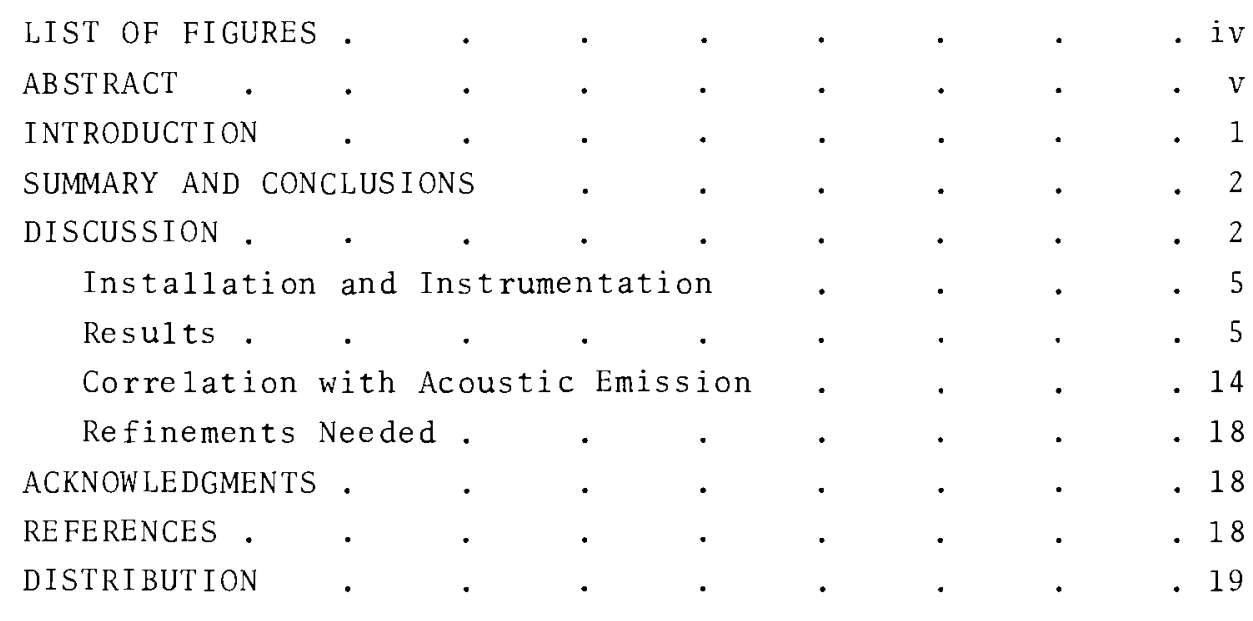




\section{LIST OF FIGURES}

1 Partial Schematic of Dresden I Nuclear Power Reactor System Showing Transducer Locations for Noise Measurements

2 Schematic of Instrumentation System

3 Response Characteristics of Transducer Used to Measure Background Noise-Dresden I, Constant Amplitude-Swept Frequency Input

4 Noise Spectrum 22 in. West Recirculation Header

5 Noise Spectrum Control Rod Thimble

6 Noise Spectrum 6 in. By-Pass Line

7 Noise Spectrum Reactor Vesse 1 Head

8 Measurement System Noise Spectrum, Transducer in Air and Connected to Electronic System Used for Reactor Noise Measurements

9 Noise Spectrum Sample-22 in. West Recirculation Header, Dresden I Nuclear Power Reactor During Start-Up and Norma 1 Operation

10 Noise Spectrum Sample-Control Rod Thimble Adjacent to Vessel Exterior, Dresden I Nuclear Power Reactor During Start-Up and Normal operation

11 Noise Spectrum Sample-6 in. By-Pass, "D" Secondary Steam Generator, Dresden I Nuclear Power Reactor During Start-Up and Normal Operation

12 Noise Spectrum Sample-Reactor Vesse1 Head, Dresden I Nuclear Power Reactor During Start-Up

13 Video Traces of Noise Signa1s, Dresden I Nuclear Power Reactor During Start-Up and Normal Operation

14 Video Traces of Noise Signals, Dresden I Nuclear Power Reactor During Start-Up and Normal Operation

15 Examples of Acoustic Emission Signals for Amplitude Comparisons with Reactor Noise Spectrum 


\title{
NUCLEAR REACTOR SYSTEM NOISE ANALYSIS, DRESDEN I REACTOR, COMMONWEALTH EDISON COMPANY
}

\begin{abstract}
$\underline{A B S T R A C T}$
Work is in progress to utilize "acoustic emission", produced as metals deform and fracture, as a means of continuously monitoring the integrity of nuclear reactor pressure boundaries. To help accomplish this, a definition of the noise field is needed because it must be considered in detecting and analyzing acoustic emission during reactor operation. In-plant noise measurements on several reactor systems will be necessary to provide an adequate definition. The first of these has recently been completed at the Dresden I Nuclear Power Reactor at Morris, IZZinois, and the results are encouraging. For this reactor, the noise field above $500 \mathrm{kHz}$, is quite low. This provides a region nominally from $750 \mathrm{kHz}$ to about $3 \mathrm{MHz}$ (where signal attenuation with increasing frequency rises sharply for ferrous materials) which is conducive to reliable detection of acoustic emission signals. Detector response to acoustic emission has been demonstrated within and well beyond this region.

Although the results of this first study can not be considered universally applicable to reactor systems, they do provide strong encouragement for continued monitor system development. They, also, define a region for beneficial effort on improved detection techniques.
\end{abstract}




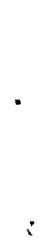




\title{
NUCLEAR REACTOR SYSTEM NOISE ANALYSIS, DRESDEN I REACTOR, COMMONWEALTH EDISON COMPANY
}

\author{
P. H. Hutton
}

\section{INTRODUCTION}

Development of new and more discerning techniques for nondestructively testing reactor pressure boundaries to assess their integrity is of general interest to the nuclear industry for further enhancement of nuclear safety. One such technique, showing considerable promise, is based on detection of "acoustic emission" or elastic waves generated in metal by the energy released as it plastically deforms and fractures. (1-4) This technique has potential application for integrity surveillance during both hydrostatic testing of a reactor system and online operation. It is, however, limited to detection of a dynamic condition, i.e., it will not detect a static flaw or discontinuity.

The USAEC, Division of Reactor Development and Technology has sponsored development work at Battelle's Pacific Northwest Laboratory for the past two and one half years directed toward development of the technology and equipment needed to apply this new surveillance technique routinely to reactor systems.

Since acoustic emission is an acoustic phenomenon, one question to be resolved is whether normal reactor background noise will mask or confuse acoustic emission information to the extent that it can not be reliably identified. The recent outage and subsequent start-up of Commonwealth Edison Company's Dresden I boiling water nuclear power reactor offered an opportunity to obtain definitive information on background noise from a boiling water power reactor. It must be noted that this study is the first of several necessary to provide a generally reliable definition of system noise as it relates to application of acoustic emission for integrity surveillance. With two major reactor designs--boiling water and pressurized water--in current use, similar measurements per. formed on several systems of each design wil1 be necessary to define the general background noise parameter. This study has, however, provided distinct encouragement and guidance to continued development effort on an on-1ine acoustic emission surveillance system. Although others* have performed noise measurements, only Battelle data are reported here.

* Phizlips petroleum Co., which is involved in the plant application phase of acoustic emission deveropment, made noise measurements on one point in paralzel with Battelze as part of this study. 


\section{SUMMARY AND CONCLUSIONS}

Acoustic noise data were collected from various locations on the Dresden I nuclear power reactor during startup and subsequent increase to full power during June 1968. The purpose of these measurements was to provide initial definition of the reactor system noise problem. This problem must be overcome if acoustic emission sensing is to be utilized to detect flaw formation and growth in pressure boundaries during operation.

In all cases but one, the significant elements of the noise spectrum appeared below $500 \mathrm{kHz}$ and especially below $200 \mathrm{kHz}$. One condition during start-up, where high flow was routed through a 6 in. by-pass line by throttling a main valve, produced a noise spectrum with significant amplitudes to $1 \mathrm{MHz}$. This, however, was a transient condition that did not appear to affect the spectrum at the other monitor points. Above $1 \mathrm{MHz}$, up to the approximately 3.5 $\mathrm{MHz}$ response limit of the measurement system, the level of signals observed was essentially that of the normal electronic noise of the monitor system. There was no significant change in the noise spectrum detected on the primary recirculation system as a function of increasing temperature, i.e., full cold flow produced the same spectral distribution as did similar flow at full power level.

The noise spectrum observed on the Dresden I reactor contains a "window" from about $750 \mathrm{kHz}$ to $3 \mathrm{MHz}$ which could be available for detection of acoustic emission. Current laboratory test work on high frequency de- tection of acoustic emission has

shown good detector response in this region. There is little incentive to work above $3 \mathrm{MHz}$ for field application purposes because the signal attenuation with increasing frequency rises very rapidly for ferrous materials above that point. This would lead to an excessive number of sensing points in order to provide complete system coverage.

The results of this test are considered encouraging to the overall project because they do indicate a useable frequency range for the detection of acoustic emission on nuclear power plants; this also provides guidance for concentration of effort on improved detection techniques. However, as discussed elsewhere in this report, they can not be considered conclusive.

\section{DISCUSSION}

Determination of the background noise frequency spectrum for typical power reactors during normal operation is a vital part of the program to adapt acoustic emission for use as a reactor pressure system integrity monitor. Ultimately, this will require noise measurements on several commercial reactors to assure that each type has been adequately considered for valid general information. Arrangements with the Commonwealth Edison Company to perform noise measurements on the Dresden I reactor provided an excellent opportunity for obtaining such data from a commercial power reactor. It is recognized that this reactor represents only one of the two major power reactor types and 
that it is an early version of the BWR concept. Conclusions derived from these initial data must, therefore, be limited to the Dresden I reactor periding acquisition of similar data from other plants.

\section{INSTALLATION AND INSTRUMENTATION}

U1trasonic, Type PzT 5-A transducers were installed at four locations on the Dresden I primary pressure system in late May 1968. The locations chosen we re:

- 22 in. west recirculation header

- A control rod thimble external to the reactor vesse 1

- 6 in. by-pass 1 ine around the main valve at the " $D$ " secondary steam generator
- Top head of the reactor vesse1 (two transducers).

A partial schematic of the primary pressure system with sensor locations indicated is shown in Figure 1. Tubular transducer holders were attached at the chosen locations by mechanica 1 means--stainless steel bands on the piping and rod thimble, and a magnet on the vessel head. Transducers were installed in the holders and coupled to the metal surface with a thin film of Genera1 Electric Co. RTV-116, hightemperature, pourable silicone rubber, which air cures to a solid condition. A11 transducers were insulated from ground at the installation point to avoid groundloop noise problems.

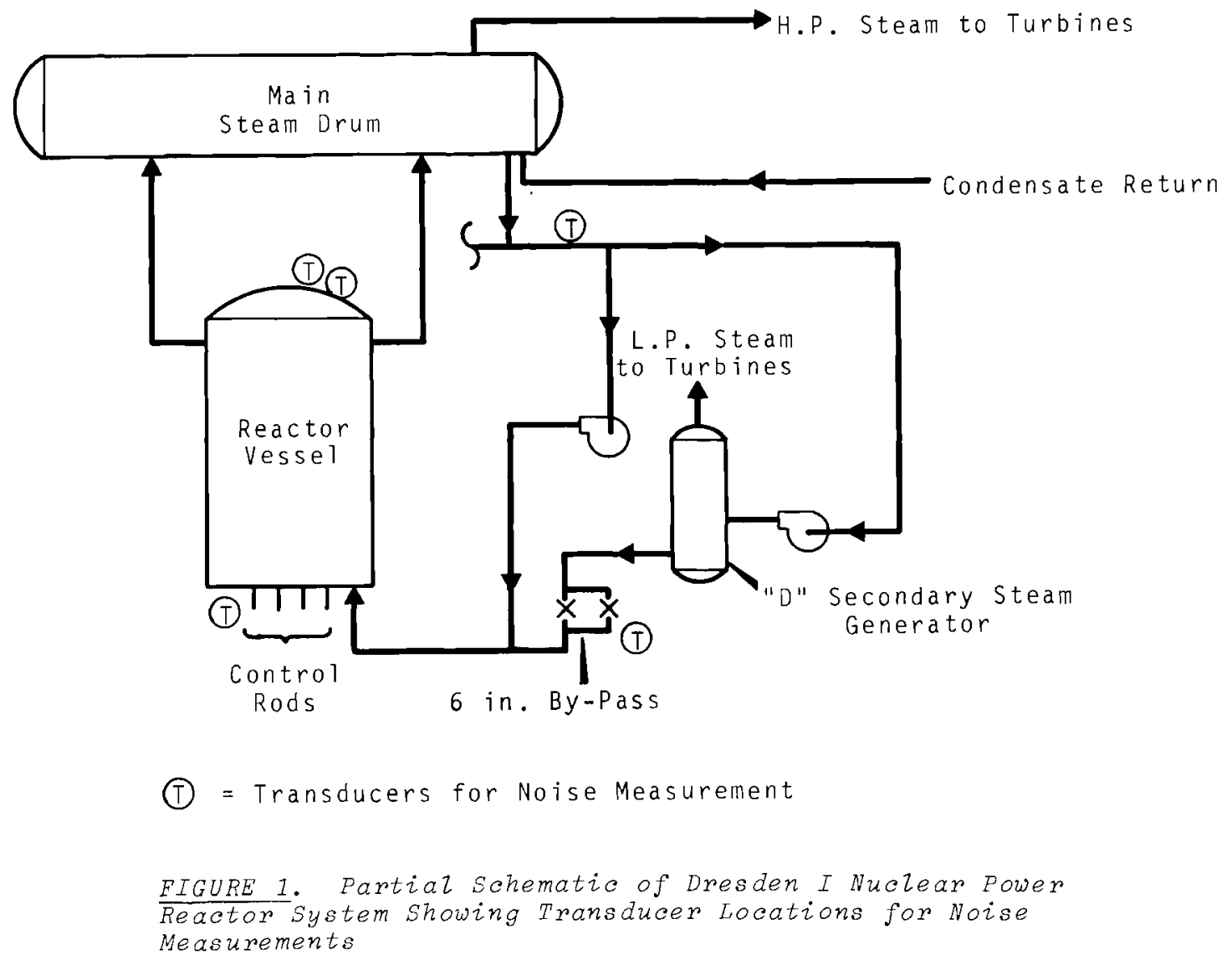


Figure 2 shows the instrumentation system used. Although it was realized that the $8 \mathrm{ft}$ long leads from transducer to preamplifier would result in some signal attenuation, this was considered a minimum length to reduce the temperature environment of the preamplifiers.

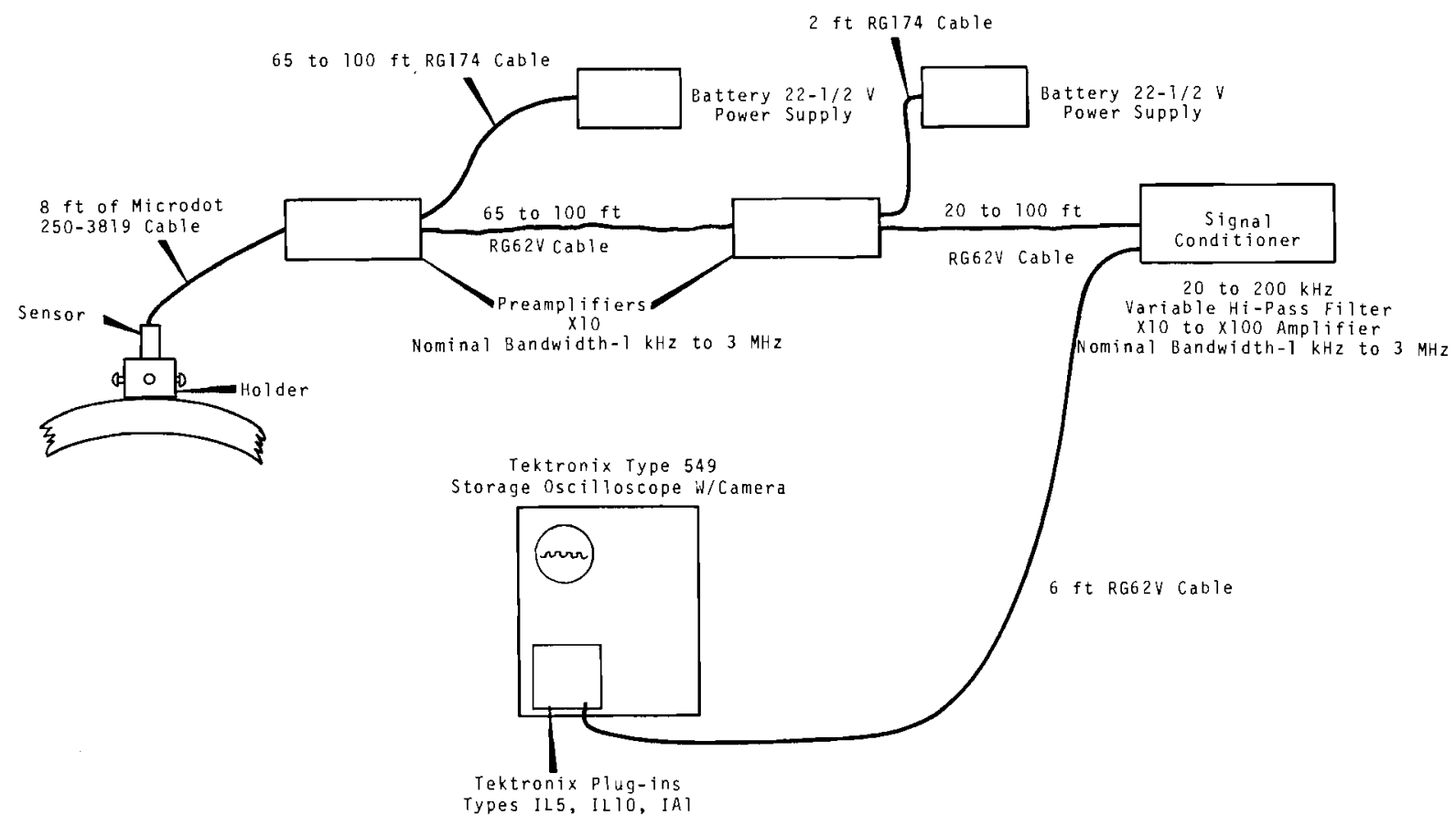

FIGURE 2. Schematic of Instrumentation System

Figure 3 illustrates transducer response to a constant amplitude, sine-wave input from 0 to $5 \mathrm{MHz}$. The immediate nonfunction of one transducer location on the vessel head following installation was apparently caused by a broken wire at the preamplifier. However, no opportunity existed to attempt restoration of this point. There were two limitations on functional longevity of the measurement system: temperature environment of the solid state preamplifiers and time at elevated temperature for the transducers. The

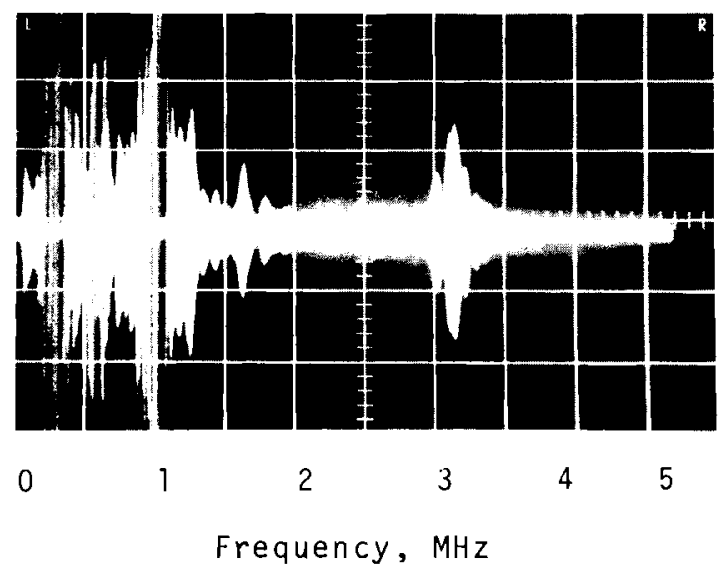

FIGURE 3. Response Characteristics of Transducer Used to Measure Background Noise-Dresden I, Constant Amplitude-Swept Frequency Input 
second point on the vessel head failed rather early in the start-up cycle because of the rapid rise in preamplifier environmental temperature to a point of component breakdown. The remainder of the sensing points remained functional for about three weeks at temperature, at which time the transducers appeared no longer reliable. Laboratory test results suggest that this was probably caused by heat induced deterioration of the transducer crystal backing and mounting epoxy (to date, none of the transducers have been retrieved for examination).

Data readout and storage were accomplished with a Tektronix Type 549 storage oscilloscope by using a $1 \mathrm{~L} 5$ analyzer plug-in for spectrum analysis from dc to $1 \mathrm{MHz}$ and a $1 \mathrm{~L} 10$ analyzer plug-in from 1 to $5 \mathrm{MHz}$. The $1 \mathrm{~L} 5$ analyzer was automatically swept through the frequency range with a resolution of $100 \mathrm{kHz}$. The $1 \mathrm{~L} 10$ analyzer with a resolution of $5 \mathrm{kHz}$ was hand swept to cover the desired frequency range within one sweep of the oscilloscope. A lAl amplifier plug-in was used also to show a trace of the actual signalwave form and amplitude. The various outputs were stored on the oscilloscope and photographed. The reliable frequency range of the overall measurement system is considered to be dc to $31 / 2 \mathrm{MHz}$.

\section{RESULTS}

Noise measurements were made on all functional points at various stages from initial start-up (full cold recirculation flow) to about $90 \%$ of full power ( 190 MW electrical) (Figures 4 through 7). This is a valid representation of the data because with the flow essentially constant, no significant change was apparent in the noise spectrum on the primary recirculation system from cold conditions to full power level. The total flow through the vessel was approximately 26,000,000 1b/hr. Each 22 in. header carries essentially half of this or $13,000,0001 \mathrm{~b} / \mathrm{hr}$ for a corresponding flow velocity of $25 \mathrm{ft} / \mathrm{sec}$. As shown in Figure 6, there were two different flow conditions and, in turn, two different noise spectrums for the 6 in. by-pass line. Unfortunately, there were no apparent means of determining with any accuracy what the flow values were in either case. The total recirculation flow splits about equaly among four secondary steam generator systems. During start-up, flow to the secondary steam generators is controlled by manipulating a main 18 in. valve, and a 6 in. by-pass around this valve (where one of the transducers was located) downstream of the heat exchanger together with a 6 in. line that completely bypasses the heat exchanger. The control parameter is steam generator cutput, and there is no direct measure of the specific flow in the various parts of this system. For a brief period early in the start-up cycle, the main valve was throttled, which resulted in a flow increase through the 6 in. by-pass. The upper curve in Figure 6 was the resulting noise spectrum out to $1 \mathrm{MHz}$. No 


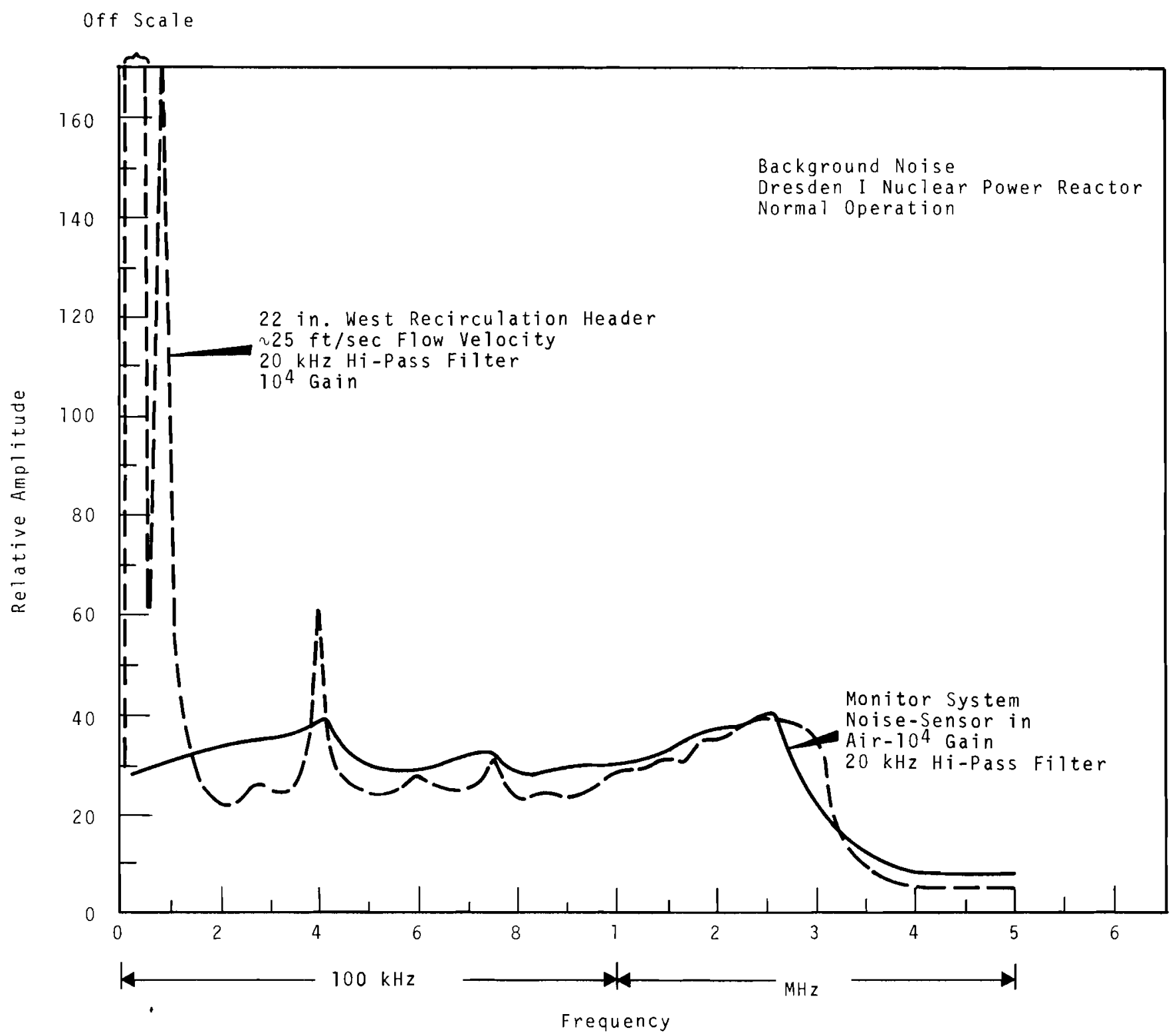

FIGURE 4. Noise Spectrum 22 in. West Recirculation Header

analysis beyond $1 \mathrm{MHz}$ was obtained for this condition; however, the spectrum falls off quite rapidly toward $1 \mathrm{MHz}$. When the main valve was opened, the noise spectrum assumed a shape very similar to that of the other points.
The noise distribution measured on the head of the vessel (Figure 7) was measured only out to $1 \mathrm{MHz}$ because of the unexpected early failure of the preamplifier in this location. 


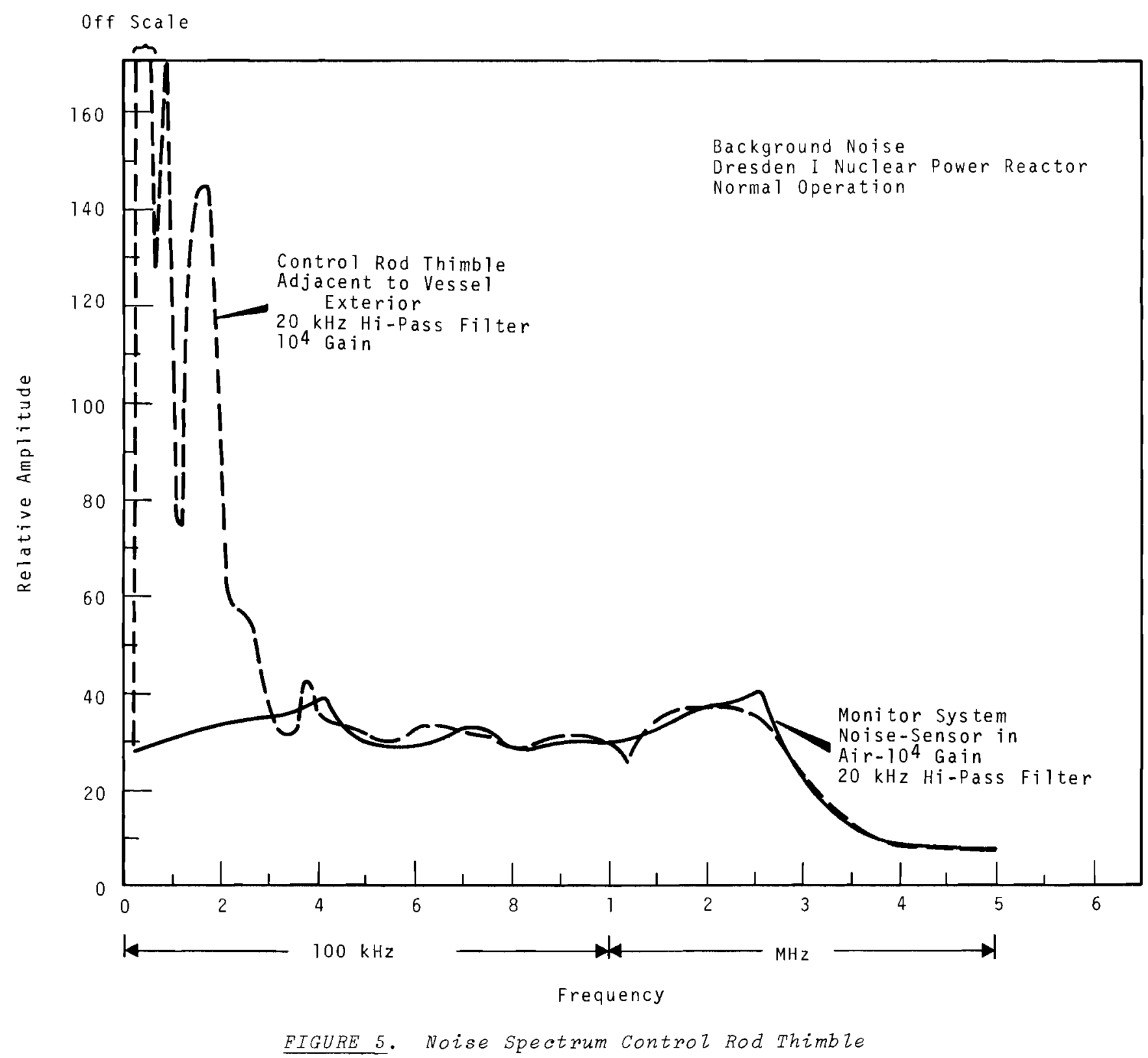

Figure 8 shows the information from which the measurement system electronic-noise spectrum, included in the previous curves, was derived. These data were generated by using the total measurement system, including a transducer which was cushioned with the face open to air during the measurements. This was done at the Dresden site and again in the laboratory with consistent results.

Typical spectral data traces for the various locations are presented in Figures 9 through 12. A relative, amplitude scale is used in presenting all of the spectral distribution information. Since the information 


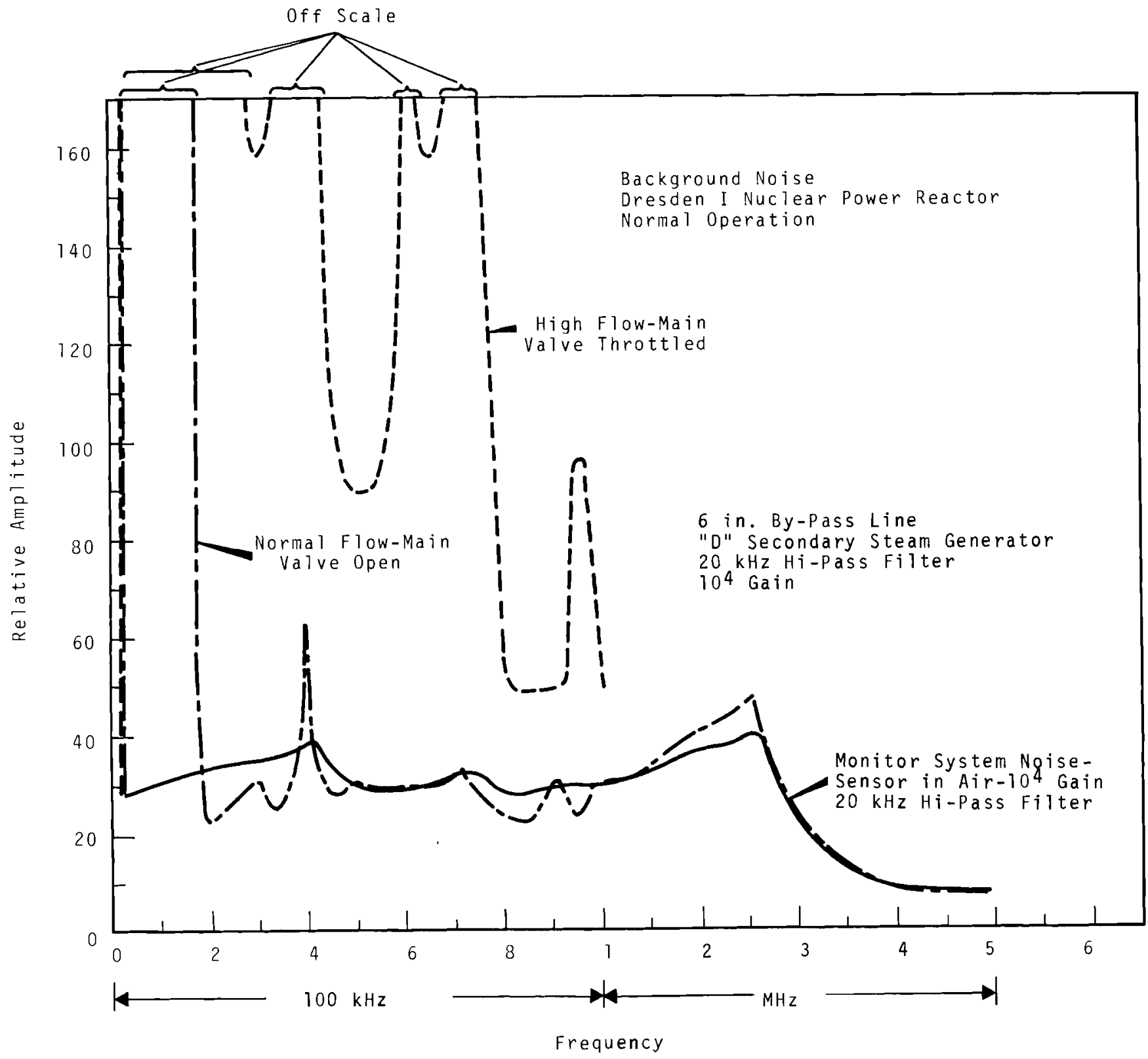

FIGURE 6. Noise Spectrum 6 in. By-Pass Line

is random in nature, a more accurate measure of absolute amplitude can be derived from the video traces of the actual signals (Figures 13 and 14). As the spectral curves show, the bulk of the noise at all locations is contained in the frequency range from dc to $200 \mathrm{kHz}$, with the exception of the high flow case for the 6 in. bypass line. In this latter case, significant noise components are evident on out to the $900 \mathrm{kHz}$ to $1 \mathrm{MHz}$ range. The preliminary conclusion drawn from this is that an 


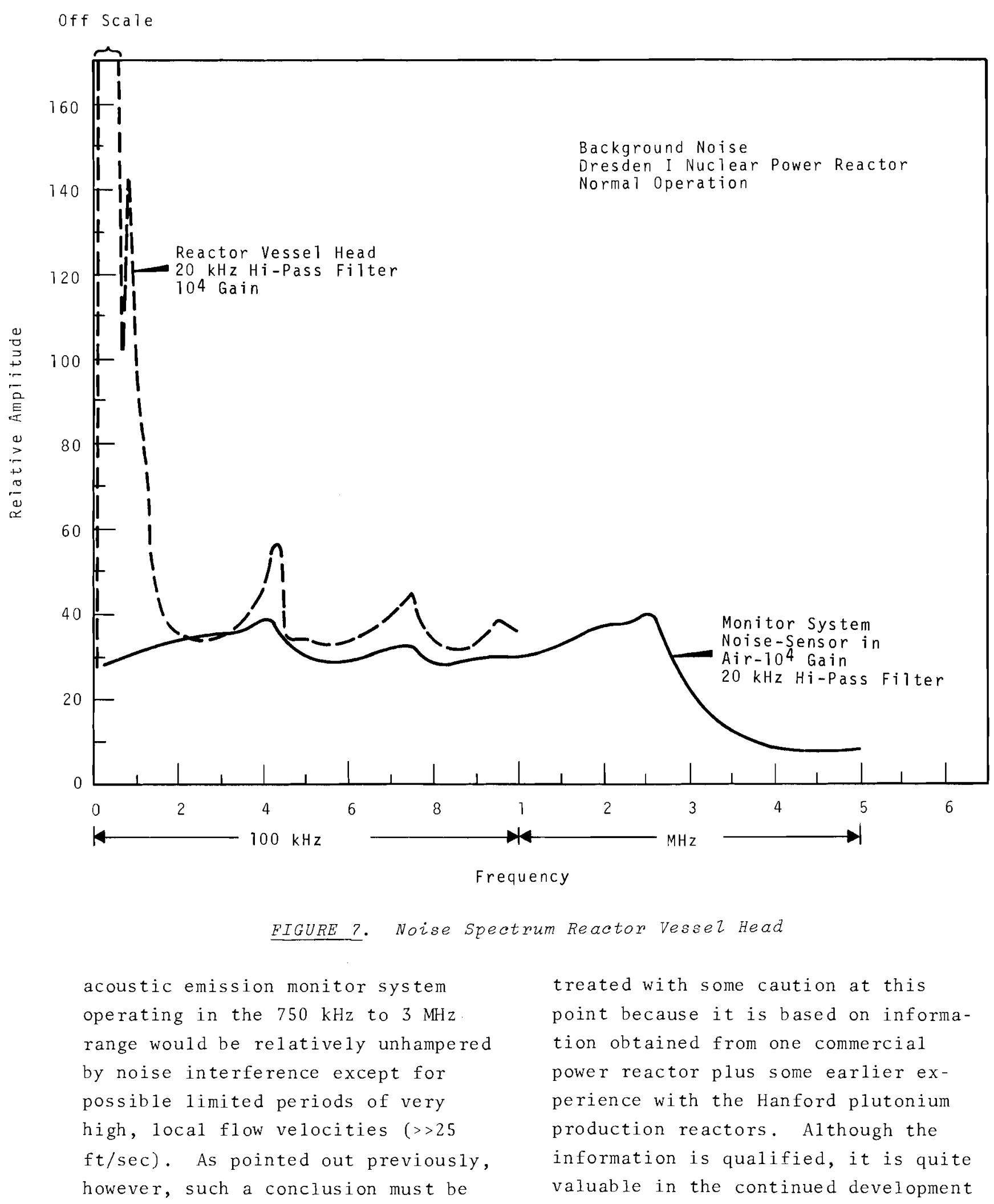




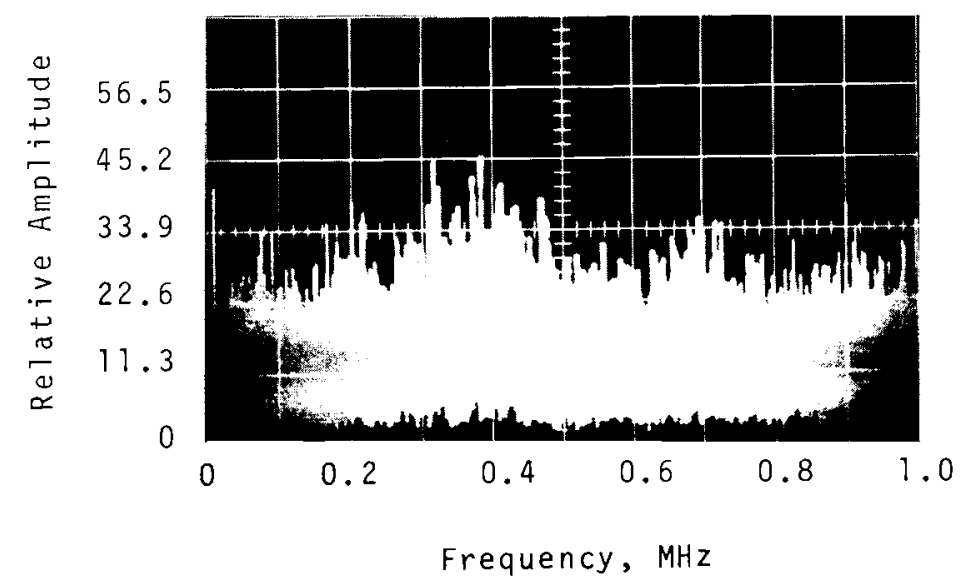

Tektronix Type IL5 Analyzer

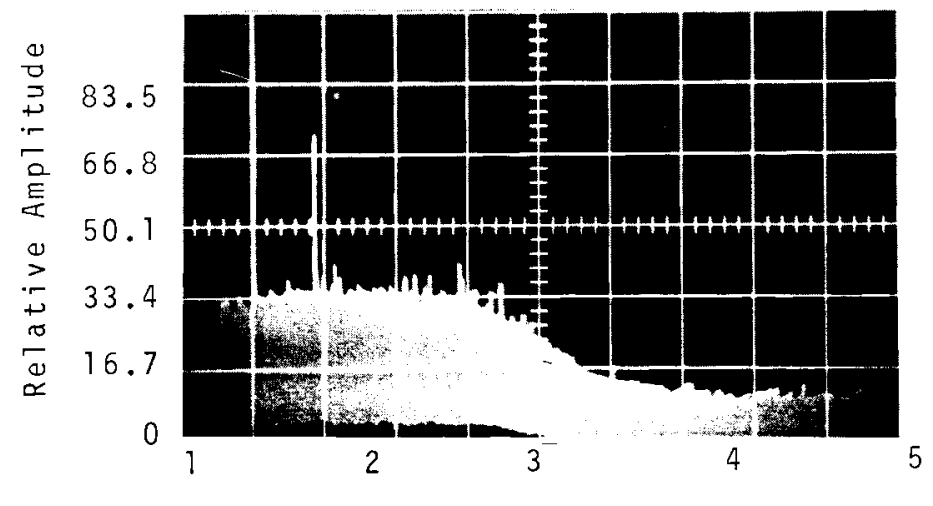

Frequency, MHz

Tektronix Type ILlo Analyzer

$20 \mathrm{kHz}$ Hi-Pass Filter Used in Both Cases

$10^{4}$ Gain

FIGURE 8. Measurement System Noise Spectrum, Transducer in

Air and Connected to Electronic System Used for Reactor

Noise Measurements 


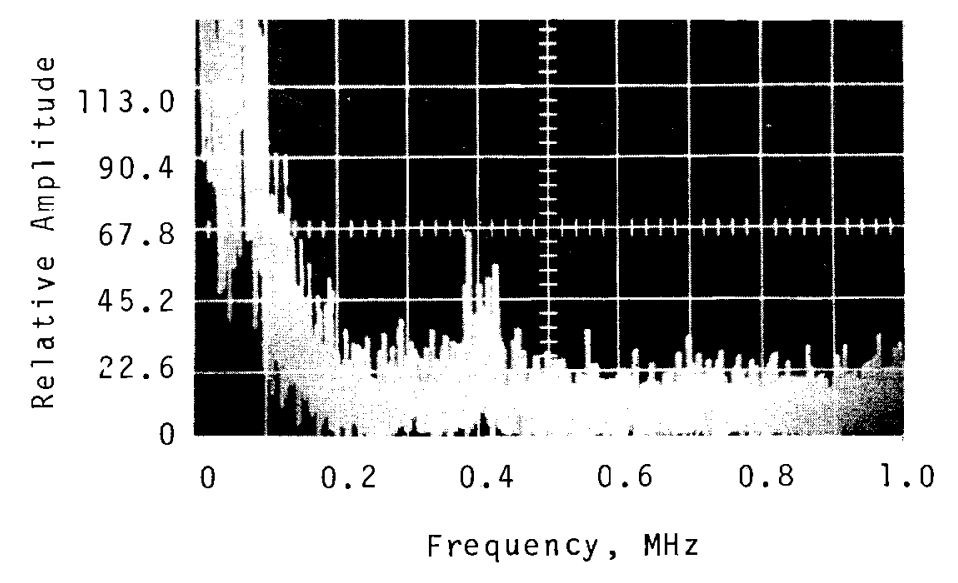

$20 \mathrm{kHz} \mathrm{Hi-Pass} \mathrm{Filter}$

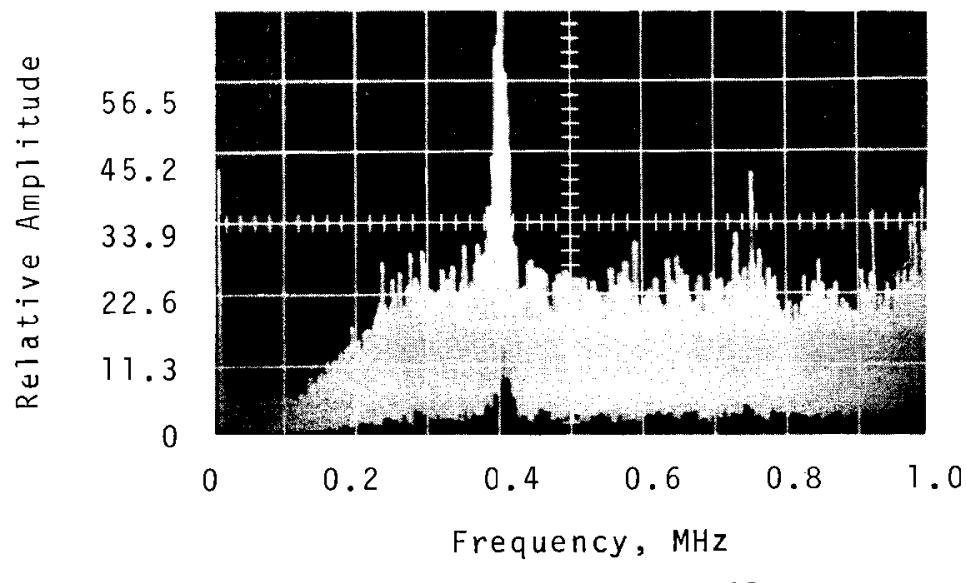

$200 \mathrm{kHz} \mathrm{Hi-Pass} \mathrm{Filter}$

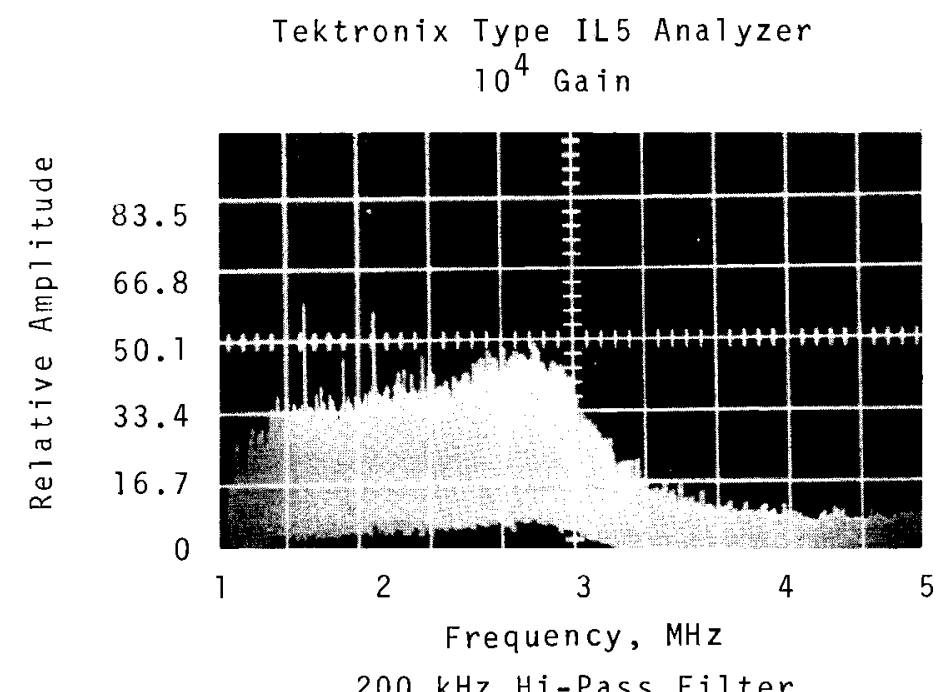

Tektronix Type ILl0 Analyzer

$$
10^{4} \mathrm{Ga} \text { in }
$$

FIGURE 9. Noise Spectrum Sample-22 in. West Recirculation Header, Dresden I Nuclear Power Reactor During Start-Up and Normal Operation 

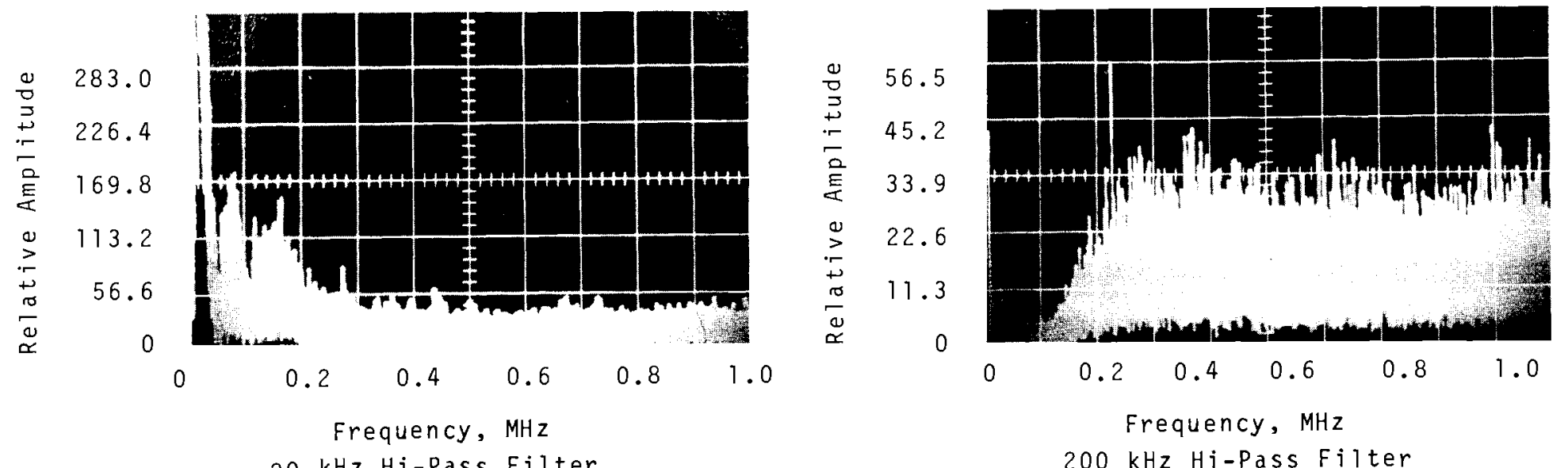

$20 \mathrm{kHz} \mathrm{Hi-Pass}$ Filter

Tektronix Type IL5 Analyzer

$10^{4}$ Gain

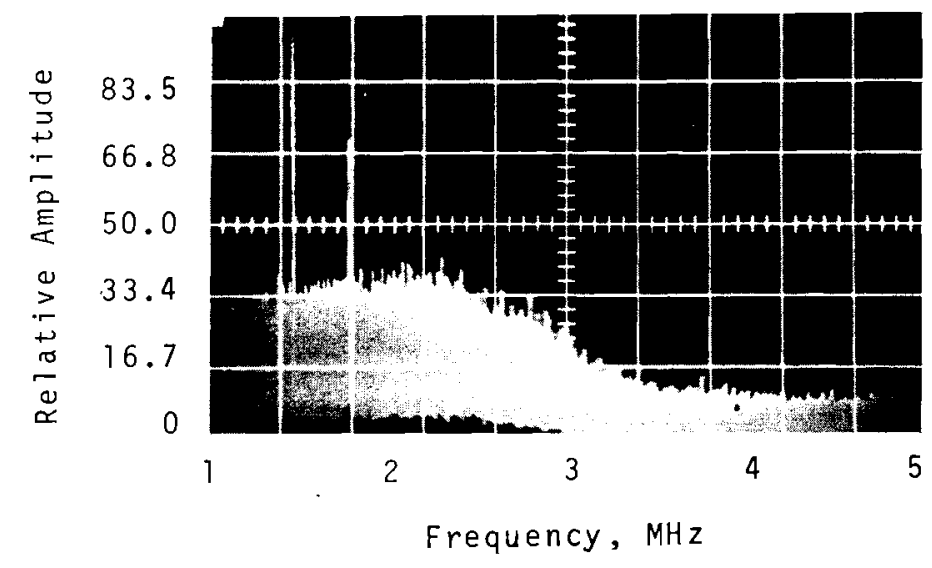

Tektronix Type ILlo Analyzer

$10^{4} \mathrm{Gain}$

FIGURE 10. Noise Spectrum Sample-Control Rod Thimble

Adjacent to Vessel Exterior, Dresden I Nuclear Power Reactor During Start-Up and Normal Operation 


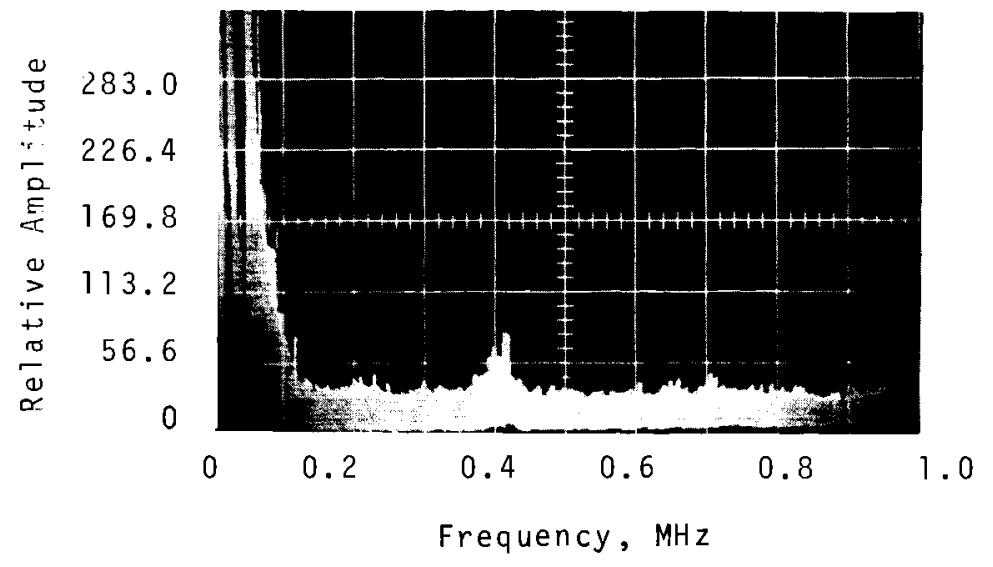

$20 \mathrm{kHz} \mathrm{Hi-Pass} \mathrm{Filter}$

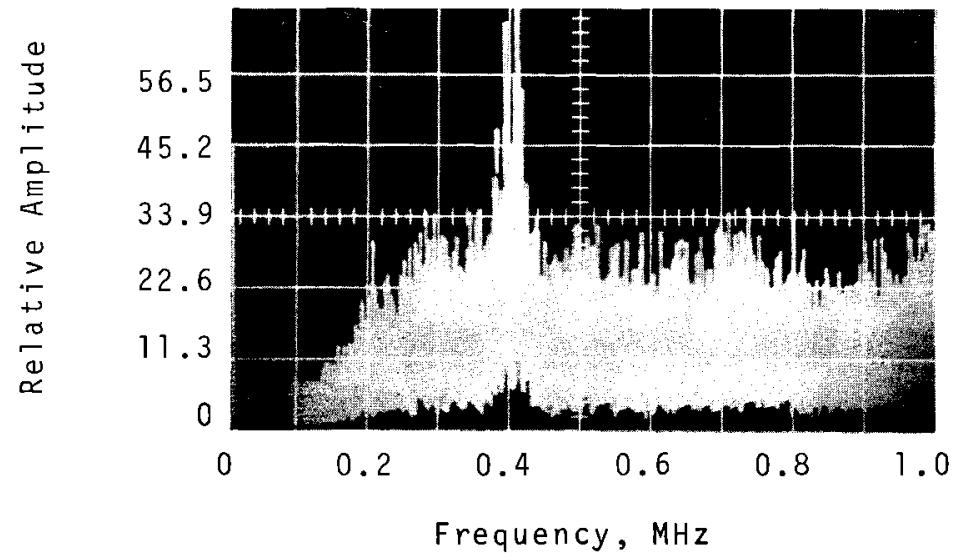

$200 \mathrm{kHz} \mathrm{Hi-Pass} \mathrm{Filter}$

Tektronix Type IL5 Analyzer Normal Flow-Ma in Valve Open $10^{4}$ Gain

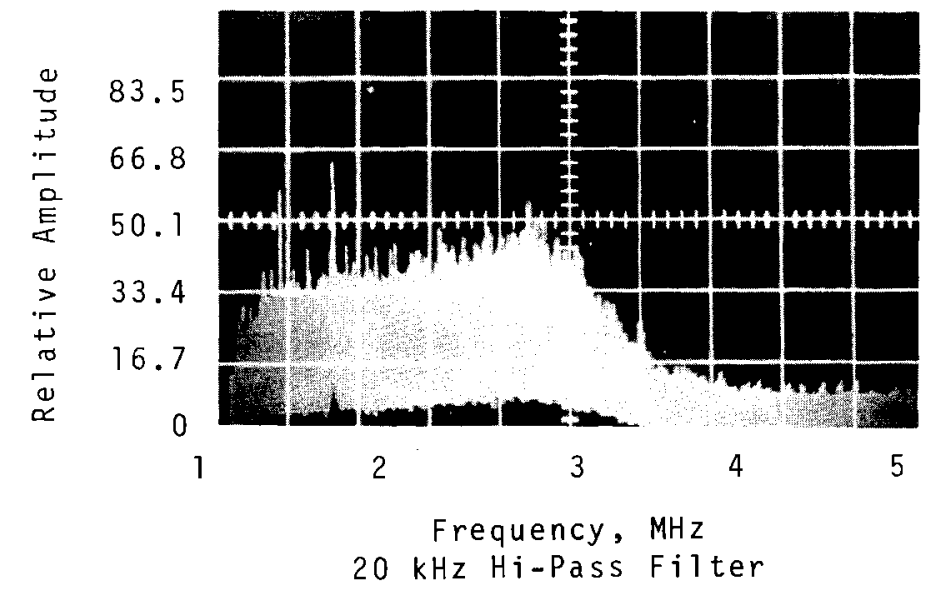

Tektronix Type ILl0 Analyzer Normal Flow-Main Valve Open $10^{4}$ Gain

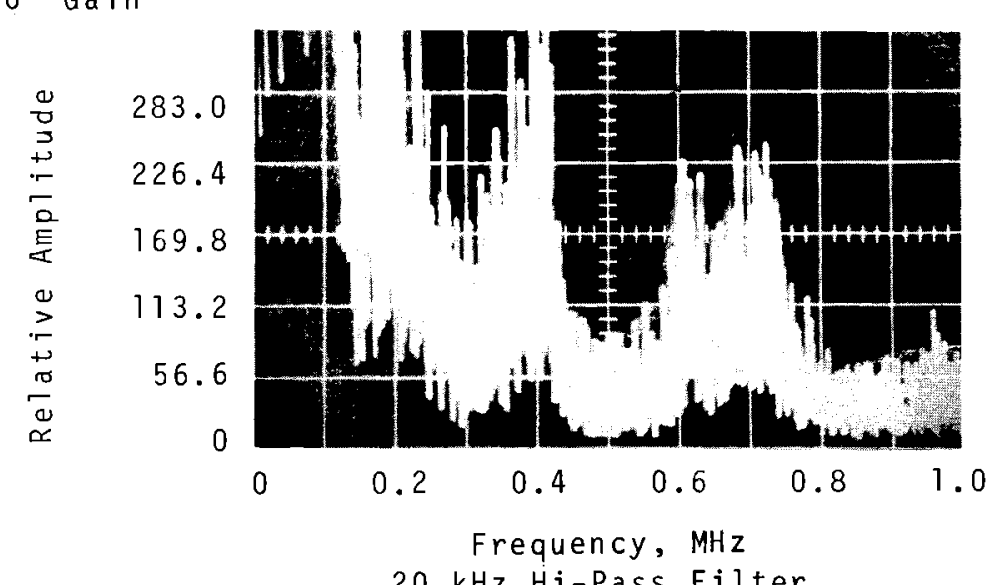

$20 \mathrm{kHz}$ Hi-Pass Filter

Tektronix Type IL5 Analyzer High Flow-Main Valve Throttled

$$
10^{4} \text { Gain }
$$

FIGURE 11. Noise Spectrum Sample-6in. By-Pass, "D"

Secondary Steam Generator, Dresden I Nuclear Power Reactor

During Start-Up and Normal operation 


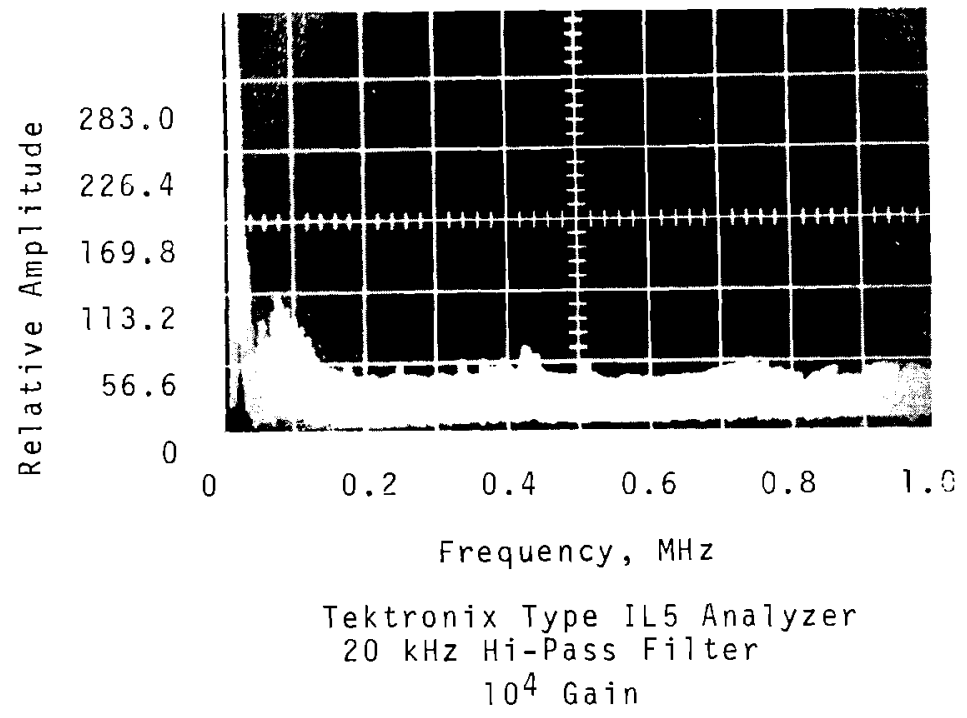

EIGURE 12. Noise Spectrum Sample-Reactor Vessel Head, Dresden I Nuclear Power Reactor During Start-Up

of a practical system to use acoustic emission as a continuous monitor for crack growth in the pressure boundaries of an operating reactor. It offers encouragement that success can be achieved, and it points to the frequency region where development work on improved detection techniques can be most productively applied.

\section{CORRELATION WITH ACOUSTIC EMISSION}

Limited follow-up work has been done in the laboratory in an effort to gain an order of magnitude comparison of the measured reactor noise spectrum and acoustic emission information (Figure 15). The illustration on the left in Figure 15 shows the response obtained by feeding acoustic emission signals as detected by a $1 \mathrm{MHz}$ transduce $r$ into the $1 \mathrm{LS}$ analyzer. Efforts to detect higher frequency, acoustic-emission information in a similar manner with the $1 \mathrm{~L} 10$ analyzer were unsuccessful because of the extremely narrow resolution "window" of this instrument. It became impractical to obtain the precise matching of the analyzer set frequency and the transducer response needed. The illustration on the right does, however, shows a video trace of an acoustic emission signal detected with a $2 \mathrm{MHz}$ transducer by use of a $500 \mathrm{kHz}$ high-pass filter.

These results are not considered conclusive, but they do demonstrate that acoustic emission information detected near the source (a few inches away) has a substantial amplitude margin over the higher frequency reactor noise measured at Dresden $I$.

The $2 \mathrm{MHz}$ video trace shows this best when compared with similar traces obtained at Dresden I. The acoustic emission signal is about a factor of 10 higher. Hopefully, this relationship can be maintained over much greater detection distances with improved techniques currently under development. 


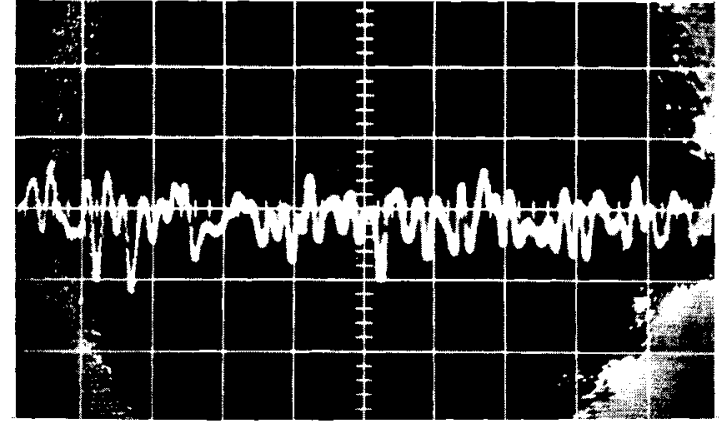

$0.01 \mathrm{~V} / \mathrm{cm}$ Vertical, $2.0 \mu \mathrm{sec} / \mathrm{cm}$ Sweep $10^{3}$ Gain into the oscilloscope $200 \mathrm{kHz} \mathrm{Hi-Pass} \mathrm{Filter}$

Measurement System Noise

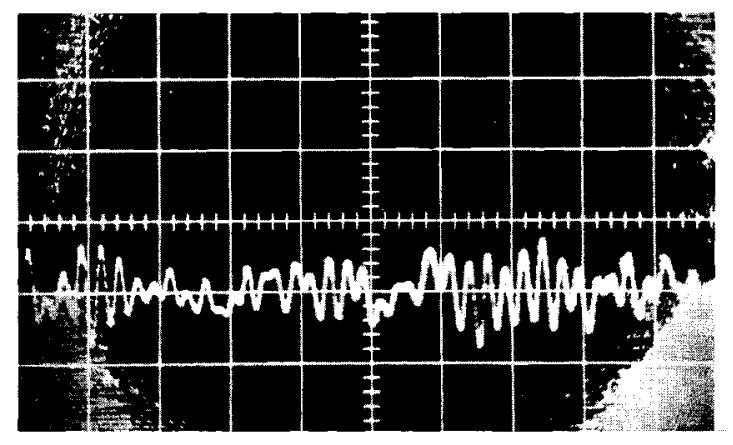

$0.02 \mathrm{~V} / \mathrm{cm}$ Vertical, $2.0 \mu \mathrm{sec} / \mathrm{cm}$ Sweep $103 \mathrm{Gain}$ into the oscilloscope $200 \mathrm{kHz}$ Hi-Pass Filter

Control Rod Thimble Adjacent to vessel Exterior

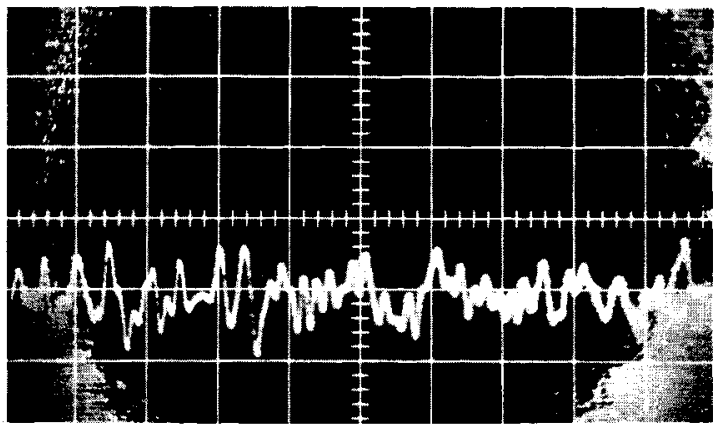

$0.01 \mathrm{~V} / \mathrm{cm}$ Vertical, $2.0 \mu \mathrm{sec} / \mathrm{cm}$ Sweep $10^{3} \mathrm{Gain}$ into the Oscilloscope

$200 \mathrm{kHz} \mathrm{Hi-Pass}$ Filter

22 in. West Recirculation Header

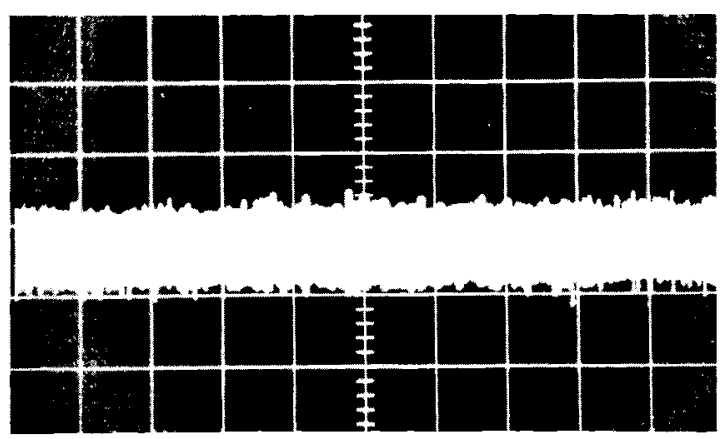

$0.02 \mathrm{~V} / \mathrm{cm}$ Vertical, $1 \mathrm{mil-sec} / \mathrm{cm}$ Sweep $10^{3}$ Gain into the oscilloscope $200 \mathrm{kHz} H \mathrm{H}-\mathrm{Pass} \mathrm{Filter}$ Reactor Vessel Head 


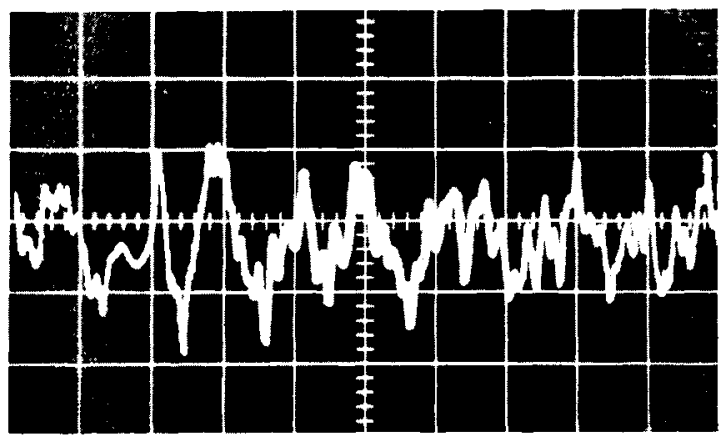

$5.0 \mathrm{~V} / \mathrm{cm}$ Vertical, $0.1 \mathrm{mil}-\mathrm{sec} / \mathrm{cm}$ Sweep $10^{3}$ Gain into the oscilloscope

$20 \mathrm{kHz}, \mathrm{Hi}-\mathrm{Pass} \mathrm{Filter}$

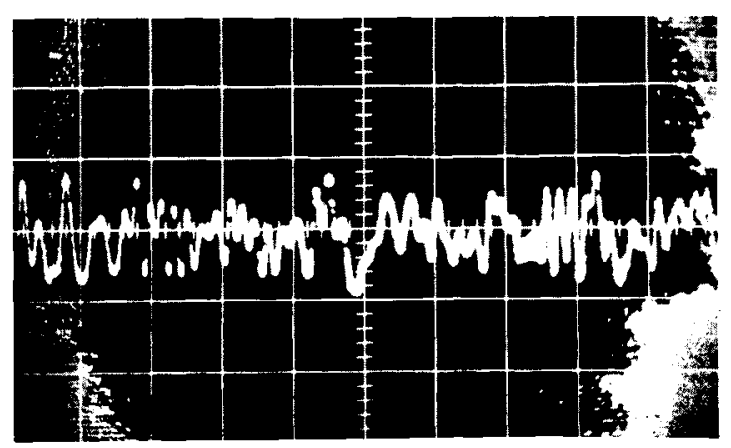

$0.01 \mathrm{~V} / \mathrm{cm}$ Vertical, $2.0 \mu \mathrm{sec} / \mathrm{cm}$ Sweep $10^{3} \mathrm{Gain}$ into the oscilloscope $200 \mathrm{kHz}$, Hi-Pass Filter

6 in. By-Pass, "D" Secondary Steam Generator

FIGURE 14. Video Traces of Noise Signals, Dresden I Nuclear Power Reactor During Start-Up and Normal operation 


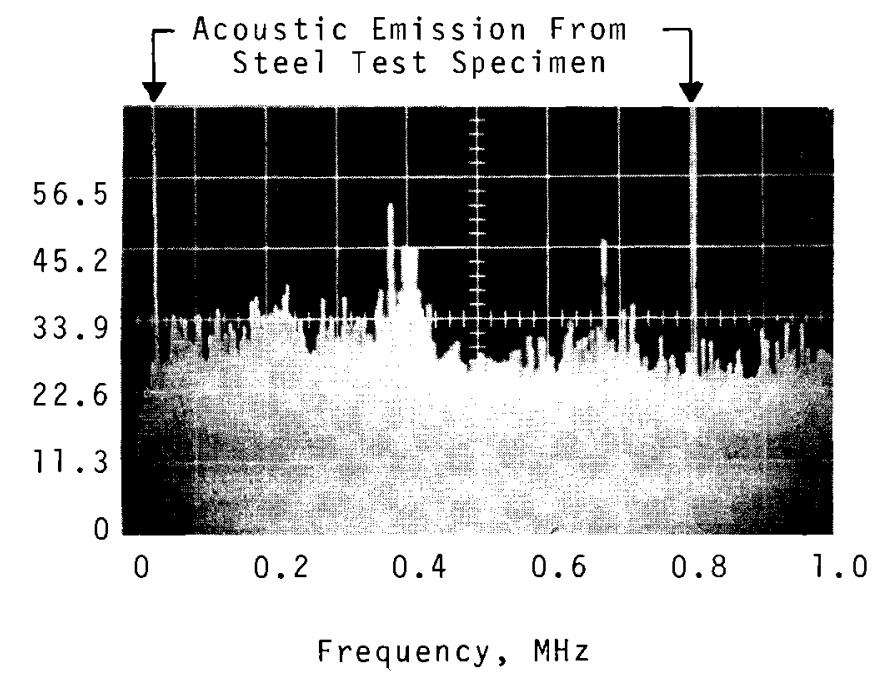

Tektronix Type IL5 Analyzer

$20 \mathrm{kHz}$, Hi-Pass Filter, $10^{4}$ Gain Acoustic Emission Signals

Processed Through Spectrum Analyzer

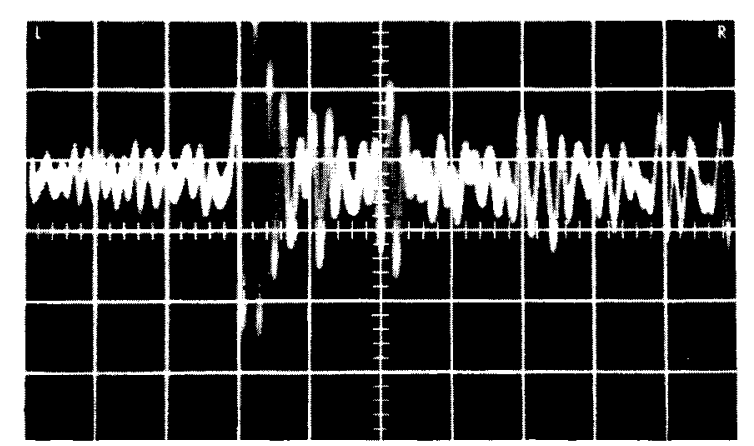

$0.05 \mathrm{~V} / \mathrm{cm}$ Vertical, $2.0 \mu \mathrm{sec} / \mathrm{cm}$ Sweep

$10^{3}$ Gain into the Oscilloscope

$500 \mathrm{kHz}, \mathrm{Hi}-\mathrm{Pass} \mathrm{Filter}$

$\checkmark$ ideo Trace of Acoustic Emission

Signal from Steel Test Specimen

FIGURE 15. Examples of Acoustic Emission Signals for

Amplitude Comparisons with Reactor Noise Spectrum 


\section{REFINEMENTS NEEDED}

The work described in this report has also served to emphasize some areas requiring attention in considering further tests of this type.

Some device such as activation foils should be installed at each transducer location to obtain a measure of the nuclear radiation field. This information is essential to a thorough analysis of the effects of environment on the transducers and preamp 1 ifiers.

Consideration must be given to either producing a preamplifier better able to stand high temperature $\left(>150^{\circ} \mathrm{F}\right)$, or devising a means of protecting the existing type amplifiers from high temperature environment.

Improved detection techniques are needed. For this type of study, this consists primarily of a transducer with a relatively flat response out to about $5 \mathrm{MHz}$ and constructed such that it can withstand months rather than weeks of continuous service at 500 to $600^{\circ} \mathrm{F}$ without significant deterioration.

\section{ACKNOWLEDGMENTS}

The author wishes to make special note of the excellent work and extra effort on the part of D. M. Romrel1, Batte11e-Northwest, in the conduct of this study.

Special acknowledgment is also in order for the outstanding cooperation by the Commonwealth Edison Company staff at the Dresden plant. They contributed much to obtain information important to the acoustic emission development program.

\section{REFERENCES}

1. B. H. Schofiezd. A study of the Applicability of Acoustic Emission to Pressure Vessel Testing, Lesselis \& Associates, Inc., AFML-TR-66-92. Wright-Patterson $A F B$, Ohio. April 1966.

2. D. L. Parry. Nondestructive Flaw Detection by Use of Acoustic Emissions, Phillips Fetroleum Co., IDO-17230. Idaho operations Office, AEC. May 196 ?.

3. H. Dunegan and D. Harris. Acoustic Emission-A New Nondestructive Testing Tool, Lawrence Radiation Laboratory, UCRL-70750. Livermore, Califomia, January 1968 .

4. P. H. Hutton. Acoustic Emission in Metals as an NDT Tool, Materials Evaluation, vol. XXVI, no. 7 , July 1968. p. 125, BattelleNorthwest, Richland, Washington. 


\section{DISTRIBUTION}

No. of

Copies

\section{OFFSITE}

1

AEC Chicago Patent Group

G. H. Lee

3

AEC Division of Reactor

Development and Technology

R. R. Newton, RDT

270

AEC Division of Technical

Information Extension

1 Atomic Energy of Canada, Ltd.

M. M. Gupta

4 Commonwea1th Edison Company

E. C. Bailey

W. I. Kiedaisch

1 Phillips Petroleum Company, NRTS

D. L. Parry
No. of

Copies

ONSITE-RICHLAND

1 AEC Chicago Patent Group

R. K. Sharp (Richland)

3 AEC RDT Site Representative

P. G. Holsted

(2)

J. B. Kitchen

$1 \quad \mathrm{AEC}$ Richland Operations Office

C. L. Robinson

3 Battelle Memorial Institute

32 Batte1le-Northwest

C. A. Bennett

R. L. Brown

J. H. Cox

K. O. Creek

G. M. Dalen

J. W. Helm

P. H. Hutton

W. D. Jolly

R. L. Knecht

R. N. Ord

H. N. Pedersen

C. B. Shaw

J. C. Spanner

J. C. Tobin

D. C. Worlton

FFTF Library/D. D. Taylor

Technical Information (5)

Technical Publications (2) 
